\title{
The Strange Case of Billy Biswas: Two conflicting realities
}

\author{
Bikki Anupama \\ anu.bikki@gmail.com
}

Kallam Haranadha Reddy Institute of Technology, Andhra Pradesh, India

Dept. of SEH, Kallam Haranadha Reddy Institute of Technology, Guntur Dt., Andhra Pradesh, India

\section{Mantri Venkata Raghu Ram}

mantriraghu@gmail.com

Vasireddy Venkatadri Institute of Technology (VVIT), Guntur, India

Dept. of SEH, Vasireddy Venkatadri Institute of Technology, Nambur, Guntur Dt., Andhra Pradesh, India

Received: April 8, 2017; Accepted: September 22, 2017; Published: September 30, 2017

\begin{abstract}
Arun Joshi presents socio-cultural conflicts between two different societies. One society is material driven and backed by the modern state apparatus like police, courts, etc. while the other is subsistence driven and is at the bottom in the hierarchy of the modern state. Indian tribal societies have been exploited right from the colonial period into the post-independence times. These two societies differ as follows: the tribal society lives on subsistence looks at Nature as a space for socio-economic, political, cultural and community, while the urban materialistic world perceives Nature as a resource to be exploited. This primordial difference has manifested as a socio-cultural conflict between these two societies. This may be due to the mutually exclusive and incorrigible nature of their social constructs which trigger perceptual obfuscation of symbiotic living. What appears to be an objective reality for one appears as subjective to the other and vice versa. This paper studies the strangeness of Billy Biswas, the protagonist of the novel in the socio-cultural milieu of conflicting realities.
\end{abstract}

Keywords: conflicts, social and cultural, modern, power structure, Indian society 
How to cite this paper: Anupama, B., \& Ram, M. V. R. (2017). The Strange Case of Billy Biswas: Two conflicting realities. Journal on English as a Foreign Language, $7(2), 159-182$.

India is regarded as one of those few countries in the world which boast of tribal societies undisturbed by the cannon of modernization. Several methods of appropriation have made the indigenous tribal societies of the world vulnerable and secretive. The first assault on them is at the level of fundamental rights. Every tribal, not just in India, believes that they are the wards of mother 'Nature.' The bountiful and myriad resources of nature are free to them. But, the 'Civil' advocates make them understand the hard way that their thoughts and practices are wrong. What tribal worshipped became pagan or uncivilized over years and almost all primitive religions were either erased or redefined in the context of modernity. Schedules V and VI of the Indian Constitution detail the independence and autonomy of tribal people in India. It is natural that tribal societies have different histories as they interacted with different non-tribal communities. Recent theories in Indian context on the tribal identity and social configuration revolve round Ghurye-Elwin debate that was captured by leading writers during the late $20^{\text {th }}$ century. The Strange Case of Billy Biswas was written at a time when India was looking forward to becoming modern after emerging from almost a certain crisis. Billy Biswas is the protagonist of the story and it is through him that Arun Joshi deals with the indigenous cultural reality in contrast with the mainstream cultural reality.

Scholars have analyzed The Strange Case of Billy Biswas in many ways. Majority of them had looked at it in the light of existentialism, alienation or search for individuality, themes much familiar to other novels of Arun Joshi. However, one feels that many scholars have missed the crucial points Arun Joshi raises through this novel. Sharma and Raizada (2013) and Vaishya (2014) argue that Billy is alienated from the modern world and finds solace only in the primitive world. Some have argued that Billy Biswas character is shaped in the dilemma of alienation, identity and individuality (Chithra \& Sankar, 2012; Abraham, 2013; Yadav, 2013). Some scholars argued that Joshi presented the conflict between modern culture and primitive way of life (Navaneethamani, 2012). It is interesting to note that scholars analyzed Joshi's Billy Biswas through the lens of nature, environment, and spirituality (Nawale, 2012; Abraham, 2013; Vanitha, 2014). Soule (2015) on the other hand analyses The Strange Case of Billy Biswas through the lens ethics and development 


\section{Summary of the Novel}

The story is narrated by Romesh Sahai (Romi). It is about the strangeness of his friend Bimal Biswas (Billy). Billy is born to an aristocratic family. His father is a judge of the Supreme Court of India (the Apex court). Though Billy was sent to the United States to study engineering, instead he joins Ph.D. in Anthropology. The novel is set in three different stages; the first stage is set in the New York in America, the second stage in New Delhi in India and the third stage in the forests of Madhya Pradesh (present-day Chhattisgarh). It is in New York that Romi first meets Billy. Romi is surprised that Billy is living in Harlem, a slum-area in New York, where Black people live. Billy says that 'White America' is too civilized for him. Billy is friendly with Tuula Lindgren, a Swedish girl, and discusses Anthropology in depth. Meanwhile, the narrator, Romi had to leave America for India due to his father's death. Later Billy too comes back to India and meets Romi. Meanwhile, Romi joins Indian civil services as IAS (Indian Administrative Officer) officer.

In between Billy disappears without any information about his whereabouts and again appears in places least expected much to the surprise of Romi. Meanwhile, Billy marries Meena Chatterjee from an aristocratic family and takes up a teaching assignment in the Department of Anthropology at Delhi University. Soon after the marriage, Billy is distanced from Meena and he seduces Rima Kaul, a relative of Meena. Billy finds a vacuum in life and unable to find answers around him, he gets dejected with the modern way of life. During one of his field trips to jungles in Madhya Pradesh, he joins tribals. He finds Bilasia, a tribal woman as the can enhance his soul.

Simultaneously, the tribals revere him as the reincarnation of the tribal King that died thousand years ago due to poisoning by his relatives. According to their belief, the flame of Chandtola (a peak) has stopped glowing during moonlit nights after the King's death. The Chandtola glows during moonlit only when the King and the Queen live happily. After Billy's union with Bilasia the Chandtola starts glowing again. As a consequence, the tribals believe that Billy and Bilasia are their King and Queen. They also believe that Billy is bestowed with super natural healing powers as he brings back Dhunia's grandson to life after remaining for two hours dead. Meanwhile, the whole family of Billy gives up their desperate search after rumors that the tigers had feasted on him. At this juncture, Romi is posted as the District Magistrate of the same area. During one of the protests by the tribals, Billy appears in order to protect Romi. Romi, though surprised, discusses several issues from the past including his desertion of his family. Though Romi keeps Billy being alive as a secret his wife shares it with Billy's wife, Meena.

Journal on English as a Foreign Language, 7(2), 159-182

Copyright (C) 2017 by JEFL, p-ISSN 2088-1657; e-ISSN 2502-6615 
Billy's father immediately visits Romi and requests him for help to regain his son. Upon which, Romi is firm and advises him against taking back Billy by force to the so-called civilized world. Billy's father through using high-level influence gathers police force to capture Billy. During this capturing a lot of commotion takes place with Bilasia blaming Romi, while Billy resists the force. Finally, Billy dies in the hands of the police with Billy's father and Romi repenting. Thus, right from the beginning of the novel the author, Arun Joshi, projects different types of conflicts associated with Billy Biswas starting from America to Delhi to Maikala hills in present-day Chhattisgarh.

\section{METHOD}

This paper uses the famous anthropological debate that shook the young Independent India soon after the drafting of Indian Constitution as its theoretical framework to analyze the socio-cultural conflicts and the consequent reality. It is interesting to note that the entire novel is set in the tradition of Ghurye-Elwin debate (Srikant, 2009). Ghurye observed that Indian tribal societies can be divided into three categories -1 . Tribes that do not want to change and revive their lost or forgotten practices despite their interaction with non-tribal societies; 2 . Tribes that want to isolate themselves from the non-tribal societies and preserve their culture; and 3. Tribes that are willing to assimilate with the non-tribal societies. Ignoring the impact of Islam and Christianity, he further argued that the indigenous people are 'backward Hindus' and hence need to be mainstreamed by merging into the mainstream society.

In other words, the modernization of the indigenous people is the need of the time. Elwin (1955) argued consistently that tribal people are different and hence called for maintaining a distinct identity for what he called 'a tribal way of life'. Interestingly, both the arguments made it clear that tribal people had no other option but to join the mainstream of Hinduism or Christianity to benefit from the modern systems. This caught many people unaware, despite promotional campaigns undertaken by the Indian government. Many questions remained unanswered in the process of assimilation and several layers of conflicts broke-out on the socio-cultural plane of India. This was further compounded by the "tribal reservation" employment, educational and political policies of the Government of India. In The Strange Case of Billy Biswas, the urban mainstream society dominates the primitive tribal one. While the urban mainstream society through power and strength both in terms of language discourse as well as coercive power limits the indigenous notion of reality as hallucination or myth; the tribal people, on the contrary, assert that they enjoy the same freedom as other living creatures in 'nature' do and cannot be governed by the mainstream social order. As a result, there is a conflict 
between two notions of realities - one reality is represented by the state-led urban mainstream society; and the second by tribal society. Both the realities come into conflict with each other making the novel relevant to present day Indian society and polity.

\section{FINDINGS}

Scholars had analyzed The Strange Case of Billy Biswas in many ways. The majority of them had looked at The Strange Case of Billy Biswas in the same line as his other novels -- existentialism, alienation or search for individuality. However, many of the scholars appear to have missed some of the crucial points that the author, Arun Joshi raises through this novel. Sharma and Raizada (2013) and Vaishya (2014) argue that Billy is alienated from the modern world and finds solace only in the primitive world. Some have argued that Billy Biswas character is shaped in the dilemma of alienation, identity and individuality (Chithra \& Sankar, 2012; Abraham, 2013; Yadav, 2013). Some scholars argued that Joshi presented the conflict between modern culture and primitive way of life (Navaneethamani, 2012). It is interesting to note that scholars analyzed Joshi's Billy Biswas through the lens of nature, environment, and spirituality (Nawale, 2012; Abraham, 2013; Vanitha, 2014). Soule (2015) on the other hand analyses The Strange Case of Billy Biswas through the lens ethics and development.

Analysing Joshi's novel The Strange Case of Billy Biswas based on themes like existentialism, alienation, individuality, self, spirituality, are all extremely common conclusions that scholars make. Her analysis is repeated for all the novels of Arun Joshi. Issues pertaining to modernity and tradition are addressed to a certain extent in the case of Billy Biswas. This is mainly due to the fact that modernity and tradition are starkly visible as two different worlds in this novel. However, the most important and different contribution in analyzing The Strange Case of Billy Biswas comes from Soule (2015) by reading the novel in the context of development. It is essential because the period that the novel was set in was the period that India was independent and young with widespread optimism about development. There was so much sanguinity with regard to modern development that there was no significant opposition to the construction of dams or any other 'development' related projects. Considering contemporary opposition to large dams and State's involvement in tribal regions, the novel appears to be highly relevant today's development issues. Nonetheless, all the scholars almost unanimously appear to have agreed about the presence of conflict in the novel. Though scholars have differed on the nature of the conflict, it is pertinent that conflict is noticed in this novel. 


\section{DISCUSSION}

The concept of assimilation of aboriginals into mainstream dialectics is a regular systematic process adopted several governments worldwide. Most often, this assimilation overlooks the disadvantages from the tribal perspective while strongly advocating the embrace of dominant practices of the specific countries or states. Consequently, the identity loss and curtailment of freedom and the denial of the basic right to natural resources made the tribal societies vulnerable. A look at the situation of aboriginals in Canada tells us that there is a problem of transition from school to work. Citing marginalization, American Indian Studies assert the need for inclusion of Native American Literature into the curriculum stressing its importance in the making of American History. The tribal resurgence in Saudi Arabia poses yet another problem where there is a conflict between the western influenced outlook and the traditional Arabian culture. The largest African nation Sudan too is no exception to the conflict of cultures triggered by successive governments that ignored the tribal diversity in the sustainable development schemes. This paper draws on the general themes of conflicts triggered by the tribal-nontribal epistemology.

Analysing Joshi's novel, The Strange Case of Billy Biswas based on themes like existentialism, alienation, individuality, self, spirituality, are all extremely common conclusions that scholars make. In this paper, issues pertaining to modernity and tradition are addressed to a certain extent in the case of Billy Biswas. This is mainly due to the fact that modernity and tradition are starkly visible as two different worlds in this novel. An interesting analysis of The Strange Case of Billy Biswas came from Soule (2015) who read in the context of development. It is essential because the period that the novel was set in was the period that India was independent and young with widespread optimism about development. There was so much sanguinity with regard to modern development that there was no significant opposition to the construction of dams or any other 'development' related projects. Considering contemporary opposition to large dams and State's involvement in tribal regions, the novel appears to be highly relevant today's development issues.

Nonetheless, all the scholars almost unanimously appear to have agreed about the presence of conflict in the novel. Though scholars have differed on the nature of the conflict, it is pertinent that conflict is noticed in this novel. This paper identifies at least two conflicts of Billy - First, in the material world when he was sent to the United States to study engineering. There he joins Ph.D. in Anthropology instead. The constant dilemma of Billy in deciding between his modern life and primitive life is manifested into conflict in the novel. This goes to the extent of his living in Harlem and downtown slums with a pseudoJournal on English as a Foreign Language, 7(2), 159-182

Copyright (C) 2017 by JEFL, p-ISSN 2088-1657; e-ISSN 2502-6615 
conscience. He finds himself a misfit in the material world. After his return to Delhi in India as a teacher of Anthropology, his conflicts take a new turn. He finds Delhi as a mere extension of the American material world and tries to feel the conflicts between the young fast growing modern state and equally fast disappearing age-old tribal societies. Second, in the tribal world of Madhya Pradesh, Billy's arrival into tribal society was marked with festivities as they treated him as the human-God and reincarnation of the tribal king. This conflict is even worse. He knows that he is no god and the beliefs of the tribes are not real. Neither could he make the tribes realize that what they think REAL is not real and what modern society thinks REAL about the tribes too is not real. A detailed discussion of the conflicts with textual examples and critical citations is presented below.

In this novel, The Strange Case of Billy Biswas, two conflicting realities are projected by the author, Arun Joshi. One reality is associated with the material world and all the comforts that it brings in; second reality is associated with subsistence culture of the tribals in Maikala hills. The reality associated with that of the material world is about earning and spending money, while the reality associated with tribal life is about freedom. Though the central theme of the novel is about the socio-cultural conflicts between these two worlds, the author depicts layers of conflicting realities in the novel. Billy Biswas often 'listens' to inner voice calling him to fulfill his duty. This when he shares with his Swedish friend Tuula, a psychiatrist, dismisses it as his hallucination. Further, it appears that the author attempts to suggest that one culture's objectivity may be subjectivity for another culture or society and vice versa. This he brings out in the conversation between Billy and his father. To quote,

All I am saying is that there are worlds at the periphery of this one, above it and below it, and around it, of which we know nothing until we are in them (p. 40).

In the discussion about a government clerk murdering a boy, Billy and his father discuss the case. While Billy argues that there might be a case of temporary insanity, his father does not accept the theory of temporary insanity. That is when Billy actually argues that there are worlds that the material world may not be aware of. Here, it is clear that Billy's father, Judge of the Supreme Court, is representing the modern state, while Billy represents the tradition in general and primitive tradition in particular. It is here that the conflict lies between Billy and other people around him. This conflict is essentially sociocultural in nature as Billy is often averse of material civilization and is always drawn towards tribal civilization. Billy finds it difficult to even communicate with his wife Meena as he does not see life in her. Billy's experience during his Journal on English as a Foreign Language, 7(2), 159-182

Copyright (C) 2017 by JEFL, p-ISSN 2088-1657; e-ISSN 2502-6615 
job at the mental hospital highlights the point about how there are different realities for different people. To quote Billy,

No, not really. The mentally ill have never interested me as such, and I came nowhere near understanding them. What interested me, I imagine, was the simple fact that here were people who looked at life from a totally different point of view. I wonder if you know that most of the people in these institutions are not stark raving mad which is the common idea of the mentally ill (p. 15).

It is this 'totally different point of view' of Billy that often comes in conflict with the view that is mainstream, modern and urban. Billy caught in between these two different points of view is in constant conflict with himself as well as the with the society around him. Billy is at peace with himself only after he leaves his family and lives in a tribal society. However, the conflict follows him and results ultimately in his death.

Billy is against uni-linear and single world view. Billy believed in pluralism and different perceptions to co-exist together. Whereas people around him appeared to have imposed their own mainstream world view and perception on Billy. In turn, Billy like a person living in harmony with nature, always followed his heart, much to the surprise of people around him. When Romi asks him about whether Billy's family know about Billy studying Anthropology instead of Engineering, Billy replies,

My parents do. My father is mad with rage. "Anthropology!" he screamed in amazement when I told him. "Anthropology! Of all things you had to go and do anthropology." He thinks the man is governed by only engineering and law and nothing else, rather a disgraceful point of view for a Justice, don't you think? (p. 25).

It is this modern technocratic led worldview that Billy is constantly in conflict with. For him, modern technology propagated a single and homogenous worldview, whereas the primitive tribal life had plural and diverse worldviews. Billy detests the modern society for the rush for reaching their goals and ambitions. To quote,

What kept us happy were the same things that have kept all the primitives happy through the ages: the earth, the forest, the rainbow, the liquor from the 'mahua' an occasional feast, a lot of dancing and love making, and more than anything else no ambition, none at all (p. 107). 
Billy uses the word 'ambition' to differentiate between the modern society and tribal society. It is ambition and the urge to perform that drives the modern society. On the contrary, the tribal society has no sense of ambition and lives in tandem with Nature. Referring to ambition Billy says that every child is born into a system with expectations of which often the child is not even aware of. To quote,

What made me unhappy, I suppose, was the awareness that all that I wanted most was just there, across the little patch of jungle, screaming to be taken, and I could do nothing but sit there in that stupid chair all tied up in a knot by a stifling system of expectations which I did not yet understand but in which, I knew, I had the misfortune to be born (p. 92).

The character, Billy (Bimal) Biswas is the epitome of this dilemma led conflict between the two societies. Even though, Billy was initially part of the materialist world and accumulating lifestyle he has a heart in the tribal society and subsistence lifestyle. It is this kind of lifestyle that makes Billy a strange man to his surroundings and people around him in the material world. Thus, the basic question comes up from the viewpoint of tribal society and life is that whether Billy is really strange or is it a social construct by the material world around him. For instance, Billy's Swedish friend, Tuula calls his thinking and imaginations about tribal societies and he being part of it as nothing more than a hallucination. Though Billy had much respect for Tuula particularly for she treating money for what it is - paper. And Tuula to do not fit into the mainstream social norms to a large extent. For instance, Billy mentions that Tuula is not interested in men and at another time he mentions that she is the inverse of man-women relation. In spite of all this Tuula calls Billy's imagination or thoughts as a hallucination. Thus, Billy has no one to speak to or share his thoughts or imaginations or his search for a true union. In order to understand the manifestation of socio-cultural conflict in the novel in Billy's character, it is essential to understand Billy in the material world and Billy in tribal society.

\section{Billy in the Material World: Part- I}

Billy is sent to America by his parents for studying engineering. But Billy is doing Ph.D. in Anthropology. Even though his parents come from an aristocratic family Billy lives in a Harlem in New York. In the first meeting between Romi and Billy, Billy is introduced to Romi as 'Engineer, anthropologist, anarchist...'. The introduction itself explains that it is difficult to 
compartmentalize Billy under any one label. In the modern world, people are often identified by their specialized skills, where as in the case of Billy there are more than one to be identified. Thus, in the introductory meeting between Billy and Romi, it comes out clear to the reader that the protagonist Billy does not believe in the labels accorded by the modern societies. This is clear in his reply to Romi's question about why Billy had chosen to live in Harlem. To quote Romi's words,

That [Harlem] was the most human place he could find, he said. White America, he said, was much too civilized for him (p. 9).

Further to quote Romi on Billy's collection of books,

I had always had a bit of interest in books, and I used to browse through his library when I had nothing to do. Two of the stacks were devoted exclusively to anthropology. The third presented a melange that, to my mind, made no sense at all. It contained everything old copies of the National Geographic Magazine to the latest pornography that was being peddled in Times Square; from learned treatises on black magic and witchcraft to a critique of the theory of relativity (pp. 11-12).

Thus, one can understand that Billy was chiefly interested in diverse issues. Learning appears to be his passion, particularly in the context of society and culture. The book regarding the critique of the theory of relativity denotes the internal opposition of Billy towards modernity. Similarly, National Geographic magazines and pornography, all appear to be denoting Billy's bent of mind towards nature and childlike innocence, where nudity is seen as natural rather than obscene or pornography.

Billy has a body of a modern man, while his soul is that of tribal person. Chiefly the conflict between a modern society and that of primitive tribal society is depicted in the novel through Billy's character. The constant dilemma of Billy in deciding between his modern life and primitive life is manifested into conflict in the novel. This conflict manifests into a larger conflict between the newly born modern nation-state - India and the age-old primitive tribal society. Explaining this conflict that Billy is undergoing, Tuula tells Romi, the narrator about how Billy feels,

A great force, urkraft, a ... a primitive force. He is afraid of it and tries to suppress it... But it is very strong in him, much stronger than in you or me. It can explode any time (p. 18). 
Tuula is in the United States for advanced training in psychiatric social work. She is also interested in tribals in India. It is this interest in her that brings Tuula and Billy close to each other. Though, Tuula is close to Billy her understanding of Billy is only partial, which is why she asks Romi if everybody in India is the same like Billy. At the same time, in spite of being Swedish her understanding of Billy is much better than many others around Billy.

For Billy modern civilization is nothing but degradation. In one of his letters to Tuula, he says,

I sometimes wonder whether civilization is anything more than the making and spending of money. What else does the civilized man do? And if there are those who are not busy earning and spending -- the so-called thinkers and philosophers and mean like that -- they are merely hired to find solutions, throw light, as they say, on complications caused by this making and spending of money (p. 69).

Billy constantly perceives himself as an outsider of the modern society. In a world of money, it is rationality and reasoning that dominate, whereas for Billy it is always spontaneity and inquisitiveness that are important. Billy constantly despises the goal setting ambitions of the modern world. For him, life has to be natural and any intervention towards accumulating material benefits is wrong.

The natural way of life comes only through strong community ties. Hence, Billy despises White America and lives in Harlem among the Black people, where the community is closely knitted and community way of life is strong. Accordingly, in the later stage of his life after coming to India, Billy again escapes to tribal communities, where community way of life is prevalent. As a result, though there are many people around Billy Biswas either in America or in India, he always felt alone. It is in this backdrop, that Billy writes to Tuula,

I see a roomful of finely dressed men and women seated on downy sofas and while I am looking at them under my very nose, they turn into a kennel of dogs yawning (their large teeth showing) or snuggling against each other or holding whiskey glasses in their furred paws (p. 69).

It is these instances that explain us the loneliness of Billy in modern cities. Whereas he appears to be at home in forests and wilderness. Billy in himself has elements of wilderness and naturalness. Romi is often surprised at Billy partially because does not involve in mainstream societal things through sophistication, but rather involves in them through intuition and spontaneity. It

Journal on English as a Foreign Language, 7(2), 159-182

Copyright (C) 2017 by JEFL, p-ISSN 2088-1657; e-ISSN 2502-6615 
is during one such spontaneous instances that Billy decides to marry Meena Chatterjee. Meena a young, beautiful and aristocratic is also a Bengali like Billy. Billy along with his intuition carries a sense of innocence along with him in dealing with the worldly things around him.

It is here that the modern psychiatry would label him as a split personality - split between modern city-based life and tribal community-based life. Billy rooted in oriental society and inspired by tribal way of life at a very young age, he found answers for his restlessness. However, only in the later stages of his life that he understands the connection between his restlessness and the tribals in the forests. This he realizes when he was in America, where he tells Romi,

Soon, very soon. I am itching to be back, to tell you the truth. But I must finish this wretched Ph.D. (p. 21).

In spite of Billy being part of the material world, he lived his life based on principles like honesty, simplicity, and chastity. Based on the abovementioned quotes from the novel pertaining to Billy during various circumstances, it is understood that Billy has consistently despised the material world. However, it was lack of clarity about the non-material world that took a long time for Billy to grow above the material world around him. Thus, finally, when he realized about the other world, he did not mind about leaving his wife, child, parents, friends, and job. While living in Delhi, Billy feels completely restless and is dissatisfied not only with his lifestyle but also with people around him. He is able to find a sense of fulfillment only in the tribal communion. Billy in tribal society played a completely different role to that of Billy in the material world. The next section discusses part-II of the novel -Billy in the Tribal Society. Based on these two parts a clear-cut distinction with regard to the conflicts that Billy as an individual is undergoing and the conflicts surrounding Billy.

\section{Billy in the Tribal World: Part- II}

Billy vexed up with the modern society and after realizing his fulfillment with the tribal society, he suddenly disappears. To quote the reason,

All of a sudden, Billy is seized by a phantom which makes him anxious to leave the so-called civilized world of greed, avarice, riches, and hypocrisy.

On one of his anthropological excursions to a hilly region of Madhya

Pradesh, Billy mysteriously vanishes. His love for the primitive life makes

Journal on English as a Foreign Language, 7(2), 159-182

Copyright (C) 2017 by JEFL, p-ISSN 2088-1657; e-ISSN 2502-6615 
him leave his wife, his only child, and his aged parents. Ignoring family responsibility filial expectations and societal obligations... (Dhawan, 1992, p. 32).

Billy based on his first encounter with tribal culture in Orissa (presentday Odisha) continues to romanticise the tribal society and community way of life vis-a-vis the degenerated modern society of which he is a part. Finally, the urge to join the tribal communion does not take place all of a sudden as mentioned in the above quote. The urge to join the tribal society has been nurtured by Billy since his childhood and all these years the disappointment towards modern society has been accumulated, which finally translated into joining the tribal community.

Though in the novel it appears that Billy has left his family suddenly, one needs to understand that emotionally he has left his family in general and wife in particular when he slept with Rima Kaul in Bombay (present-day Mumbai). Scholars like (Dhawan, 1992) argue that Billy joining the tribal society was sudden and it appears to the reader that it was sudden. If one reads his childhood experience as mentioned above in Orissa it can be understood that it was not a sudden decision on the part of Billy. For instance, in his letters to Tuula, he mentions his feeling of being an outsider in the civilized world,

When I return from an expedition, it is days before I can shake off the sounds and smells of the forest. The curious feeling trails me everywhere, that I am a visitor from the wilderness to the marts of the Big City and not the other way round (p. 69).

The feeling of alienation has been accumulating since Billy's seduction of Rima. This seduction of Rima by Billy is similar to the seduction of people of the material world. Billy repents deeply the seduction of Rima due to which he alienates himself from his family. It is this alienation that Billy wants with the material world. For Billy, here the concept of alienation is positive in nature that allows the fulfillment of his senses. Also, he distanced himself from his family much before he left for the jungle. Billy joining the tribal society was long pending and it just happened on a particular day, rather than suddenly. To quote,

Come, come, come, come. Why do you want to go back?... This is all there is on earth. This and the woman waiting for you in the little hut at the bottom of a hill. You thought New York was real. You thought New Delhi was your destination. How mistaken you have been! Mistaken and misled. 
Come now, come. Take us. Take us until you have had your fill. It is we who are the inheritors of the cosmic night (p. 88).

Billy's arrival into tribal society was marked with festivities as they treated him as the human-God and reincarnation of the tribal king. He has ascribed mystic and healing powers. Billy drives a tiger, brings back a boy to life. Billy plays the role of priest, king, healer, in the tribal society and becomes one of them.

Ten years after Billy's disappearance when everybody believes that he was taken away by a tiger, he appears in front of Romi, the District Collector, with his characteristic greeting -- "old chap". Billy during one of his field trips with his Anthropology students he disappears. During this field, Billy undergoes severe trauma between modern society and tribal community. This trauma is cleared only when he sleeps with Bilasia, niece of Dhunia the tribal headman. After Billy and Bilasia's union is complete the Chandtola - the whitefaced cliff - comes to life. The glow of Chandtola vanished, as per the belief of tribals, thousand years back when their King was killed treacherously. After the king's death, his wife Devi immolated herself on the king's pyre. Since then the glow of Chandtola on moonlit nights disappeared. According to the myth, the glow is to return only after the reunion of the king with the Devi. As Dhunia tells Romi,

Devi, his queen, immolated herself on her husband's pyre, prophesying that she would return when her husband returned to the forest. And at her return, Chandtola would glow again on moonlit nights. So you see...he can be no other than the king. And it is his wife that has taken abode in Chandtola (p. 113).

He further adds,

Bilasia is only a wife of this perishable world. It is Devi Mata who has been his companion for five thousand years, from one life to another. It is from Devi Mata that he gets his magic (pp. 113-114).

The problem with this kind of narration is one does not know where to draw the line between reality and myth. This is all the more difficult because a section of the people (in this case the tribals of Chandtola) believe it as truth, while a section of people (like that of Romi and people in Delhi) believe it as fiction. Essentially, it is this conflict that the author Arun Joshi depicts in the novel. This conflict is socio-cultural in nature. It is the same kind of conflict that Billy argues with his father, about a murder case, during dinner with Romi. At 
this point, Billy raises the issue about how one would know what is on the 'other side'?

The conflict presented here is the age-old conflict that the modern society has with regard to primordial loyalties, traditional societies, and tribal communities. At one level modern society is driven by reason, science, and rationality, while tribal and primitive societies are driven by trust and belief systems, where the notion of reason and rationality is very limited. While the modern society believes in science and reason, the traditional societies like the tribal societies believe in trust and myth. Thus, it is also conflict between the two societies vis-a-vis their belief systems. Belief systems of any society are the product of socio-cultural interaction at various levels. Thus, this conflict is rooted in the socio-cultural differences between these two societies.

In the novel, The Strange Case of Billy Biswas, the conflict ends with the death of Billy himself in the hands of a constable. It appears that the chain of events actually led to Billy's death almost as if the author had conspired against Billy. For instance, knowing well that Billy would not come back and his repentance regarding his relation with Rima, it appears that the author ends Rima's character in the novel. The seduction of Rima is the pinnacle point in Billy's life to move search of self-fulfillment. It is also a symbol of how much the modern civilized society had corrupted Billy. To quote Billy,

It gradually dawned on me that a tremendous corrupting force was working on me. It was as though my soul were taking revenge on me for having denied it for so long that Other Thing that it had been clamoring for. "Here, you swine, if you haven't the guts to break away from this filth, well then, I am going to wallow in it until it makes you sick." (p. 135).

Billy laments that in the seduction of Rima, his soul got degenerated and it was this degeneration that Billy resented. The personal dilemma and conflict that everybody in the society undergoes are what Billy hints at. The author presents the dilemmas and conflict of a person in modern society through Billy's character. At one level, given the dilemmas and solutions, the novel The Strange Case of Billy Biswas appears to be the continuation of the novel The Foreigner by the same author. Presenting the dilemmas the author takes Billy to the jungle by showing it as one solution.

Billy cures the long pending migraine of Romi's wife, which in turn leads to her inquiry with Romi about her cure. Finally, when Romi discloses to his wife that Billy is alive, she, in turn, shares it with Meena. Thus, a chain of events follows the trace of Billy, which ultimately leads to his death. In spite of Romi's 
pleadings, Billy's father, former Supreme Court Judge, uses his influence to initiate police action in order to take Billy back to the civilized world of Delhi. In the backdrop of Billy's resistance, the police shoot him resulting in his death. Thus, symbolically there is no coming back of Billy to the civilized world.

Here one can notice the power balance between the modern state and the tribal society. State's power appears to be omnipresent and is based on reason and rational with no place of tribal myths and belief systems. However, when the myths and belief systems are strong enough to challenge the authority of the state, like in the case of Billy refusing to go back in spite of police action, the state uses force to maintain its sovereign authority. In other words in the backdrop of socio-cultural conflict the state enters to mediate in order to maintain its authority. Thus, in the case of Billy the state involves in order to restore normalcy, however, normalcy, in this case, restored only through the killing of Billy Biswas. The conflict here is essentially between Billy's freedom and the people trying to stop Billy from realizing that freedom. The state has rendered its full support to the people trying to stop Billy realize his freedom. During a conversation with Rele, the Superintendent of Police, Romi says that Billy's freedom is being threatened,

By his father, his wife, my wife, by the so-called organized civilized society and its instruments, by people like you and the Chief Secretary by that awful squad of armed police, by the old men, you just spoke to (p. 156).

It is ironical that the state's promise of safeguarding freedom has been violated by the state itself through its apparatus like the armed police. The conflict again is very much visible between Billy's understanding of freedom and the modern society's understanding of freedom. The state ironically stepped into this conflict only to maintain status quo. The misperception of about Billy's notion of freedom on the part of modern society gave birth to the conflict between the modern society and the tribal way of life. When Rele questions Romi about what is Billy to him, then Romi replies

You won't understand, Rele. But that is beside the point. I am not here because he is something or the other to me personally. I am here because I think that man's position is being grossly misunderstood; because his freedom is threatened (p. 156).

Romi while preparing a report after Billy's death mulls over how the modern society has bracketed Billy in a particular frame. The society creates frames and attempts to fit everyone into one or the other frame. A frame which is mainstream in nature has considerable recognition, where as a frame which 
questions the status quo of the society has considerable negative recognition. Based on Romi's report Rele is transferred, while the constable is suspended. In this regard, to quote Romi

I ought not perhaps to have blamed them. They were only the representatives of a society which, in its middle-class mediocrity, bracketed men like Billy with irresponsible fools and common criminals and considered it their duty to prevent them from seeking such meagre fulfilment of their destiny as their tortured live allowed (p. 166).

The society coupled with state's power attempts to maintain status quo in order to continue its authority and power. People like Billy appear to be questioning to the status quo authority and power of the state on the one hand and conventional methods of the society on the other. Society in order to safeguard and protect itself essentially 'brackets' or frames people like Billy often as mad. This is what Romi refers to in retrospection and laments how proper freedom is not accorded to people like Billy who think and act out of the box. As Michel Foucault argues, the power attempts to discipline any odd or deviant behavior in the society through mental asylums and jails. In that sense, the man-hunt for Billy by the police is an attempt to discipline Billy. It is in this process that Billy is ultimately killed.

The conflict between modern society and tribal society is at one level socio-cultural conflict in nature and economic at another level. For instance, Billy talking to Romi about Tuula says,

Another thing that attracted me to her was her total disregard for money. She was the first person I met for whom money had no value. Since I came here, I have met several others -- my present wife, for example -- but she was the first... She believed that to survive man needs a minimum of goods which must either be given to him by society or he must receive the exchange to procure them. This minimum, however, is very, very low, much lower than people imagine, and except in times of great calamity, like war or famine, easily available. Once the society or your profession ensures this minimum, you should devote all your energies to the full exploitation of your gifts -- endowments she called them -- gifts that you are born with, and in the process contribute as much to the society as you can (pp. 1267).

One of the primary conflicts that Billy had with the modern society is with regard to accumulation. He detested the idea of accumulation of wealth beyond one's needs. On the other hand, the tribal community led a life that is 
based on subsistence and hard work rather than accumulation. It is this subsistence and hard work that attracted Billy immensely towards tribal society. He further tells Romi about why he was dejected with the modern society. To quote,

What got me was the superficiality, the sense of values. I don't think all city societies are as shallow as ours. I am, of course, talking mainly of the so-called upper classes. I didn't really get to know others. I don't think I have ever met a more pompous, a more mixed-up lot of people. Artistically, they were dry as dust. Intellectually, they could do no better than mechanically mouth ideas that the West abandoned a generation ago. Their idea of romance was to go and see an American movie or go to one of those wretched restaurants and dance with their wives to a thirty-year-old tune (p. 128).

The flashing of wealth and false notions of intellectualism are the major problems of modern society. For Billy the modern society is bankrupt and shallow. This according to Billy is the main problem of the modern society. Billy further says,

The only thing that I could see them worrying about was Money: why couldn't they make more of it (p. 129).

In this process of making money, Billy says that the modern society has become dry and artificial. Whereas the tribal society, on the other hand, continues to be creative and full of life. Compared to the modern society, the things that make tribal society happy according to Billy are very simple, the earth, rainbow, the forest, occasional feast, the mahua, dancing, and lovemaking (p. 107). For instance, soon after the dinner at Billy's house, Situ, Romi's wife passes remarks against Meena,

Did you see how she looked me up and down?... As if she herself was no less than Miss India or something. Did you notice her hair? (p. 52).

Billy was actually lamenting how shallow modern society has become by turning trivial issues into big ones. Further, when Romi tells Billy about Meena's boutique, a broad smile plays at the corners of Billy's mouth (p. 79). To this Billy says,

I can't imagine Meena doing something that did not make money (p. 79).

It is the above factors like hypocrisy, urge for money and accumulation that Billy is frustrated heavily about the modern society. Billy, in addition, also 
says how the decision to leave modern society was fuelled to a certain extent by his wife, Meena's attitude. To quote,

It was just ill-conceived, ill-fated you might say. It was ill-fated like a ship. Only one chance in a thousand can save such a ship. And only one chance in a thousand could have saved my marriage. It might have been saved if Meena had possessed a rare degree of empathy or even a sufficient idea of human suffering. These, I am afraid, she did not have. Her upbringing, her ambitions, twenty years of contact with a phoney society -- all had ensured that she should not have it. So the more I tried to tell her what was corroding me, bringing me to the edge of despair so to speak, the more resentful she became (p. 133).

Compared to the modern society, Billy's tribal society is less complicated and more open that sustains on subsistence. The conflict is between Billy's understanding of life and his parents and wife's understanding of life. This conflict ultimately leads to Billy's death. The conflict is basically due to the incongruence understanding of life, society, and culture. When Romi asks Billy to write about the events that took place in his life to his family, Billy replies saying,

I have often thought of doing that, but I don't think it will work out. They won't understand. If they ever get hold of me they will not leave me alone. And you know what havoc it will play with my life here (p. 109).

In one of his letters to Tuula, Billy laments,

I sometimes wonder whether civilization is anything more than the making and spending of money. What else does the civilized man do? (p. 69).

Unable to compromise by following the mainstream dictums, Billy rejected the modern society and moved to the forest. Billy's joining of tribal society is to be seen as a protest against the modern society.

The dichotomy between the modern society and tribal society is the conflict that Billy undergoes continuously in the novel. It is this conflict that is presented right from the beginning. Though Billy is in the midst of civilized modern society, yet he is aloof and detached to it because of this dilemma. Only when he gains clarity that he leaves for the forest. To quote Billy,

I had two clear choices: I could either follow this call, this vision, whatever the cost, or be condemned to total decay. I suppose most men are faced with similar questions some time or the other...Any worth its name is drastic. It 
is another matter that we whittle it down or gloss over it until it ceases to be drastic. At the same time, it ceases to be meaningful either. Sometimes I think the human mind is equipped with a built-in apparatus for compromises. As soon as you are faced with a different choice this apparatus is switched on. It runs about here and there, brokering between various parts of man, rationalizing this, postponing that, until what is left is the conventional expedients of the age and hardly a choice. Deep down we are afraid that the price of making such choices is terrible, not realizing that the price of not making them is even more terrible (p. 136).

It is here that Billy explains, how essential it has been for him to solve his own personal dilemma instead of getting caught in the phantoms of modern society and becoming corrupt. Billy also tells that all human beings suffer from certain dilemmas when they have to make choices. Not realizing the need for making a choice, humans often end up compromising thinking that making a choice would be costly. In the process what they do not realize is that compromising is actually much more costly. According to Billy, that cost is 'soul', and Billy was not ready to pay that cost. In spite of Billy being in the forest with Bilasia for three months, his inner-self is undergoing a conflict whether to go back to Delhi or stay in the tribal society. To quote Billy,

I had been in these hills around three months when I started to feel guilty about what I had done. After all, I knew I had been pretty brutal as far as my family was concerned. It got to be so that I could barely sleep at night. I quarreled with everyone including Bilasia....Finally, I announced that I was going back...On the fifty days I started for Delhi. I sat down here for a bit of rest....The moment I sat down, my mind went blank. All my willpower drained out of me. I felt as though I were in the presence of Fate. I knew I would never be able to leave these hills alive (p. 132).

Billy's dilemma was present right from the beginning of the novel. In an attempt to resolve this internal conflict Billy goes in search of fulfillment and for the right choice. In the process he seduces Rima, he is alienated from his family and surroundings. He is in constant search of soul fulfillment and the purpose in life. A sense of vacuum surrounds Billy. The conflict is finally resolved in the form of Billy leaving the so-called civilized society in favor of tribal society.

Once Billy resolves his inner conflict, then the larger conflict between Billy and the modern society starts in the form of Billy's father, Mr. Biswas and wife Meena coming in search of him to the forest. At this juncture, Romi, the District Collector does not help Mr. Biswas in searching Billy. Mr. Biswas through his influence contacts the Chief Secretary of the state and gets state's

Journal on English as a Foreign Language, 7(2), 159-182

Copyright $\odot 2017$ by JEFL, p-ISSN 2088-1657; e-ISSN 2502-6615 
help in the form of police. Thus, the conflict turns into a man-hunt for Billy. In the conflict that follows the man-hunt for Billy, he ends up killing one constable. As a result, larger force is put in place to hunt down Billy, which ultimately results in his death. Finally, Billy's father and wife could not take more than the ashes of Billy back to Delhi. Thus, Billy did not compromise on his choice in spite of death chasing him.

\section{CONCLUSION}

The novel, The Strange Case of Billy Biswas, in the true sense of the name is a 'strange' novel. The author discusses deep philosophical questions in the novel in a very simple language without the help of jargons. As mentioned earlier, many scholars had analyzed this novel as evidence for dealing with larger and in-depth philosophical questions like alienation, individuality, and existentialism. Though such philosophical concerns might be present in the novel, however, the novel is much deeper than that. For instance, the novel is essentially about the conflict between the materialistic world and the world of subsistence. There are again two layers of conflicts in the novel. Conflict associated with Billy and his inner self. His dilemma about his hallucinations and the society around him is the first conflict. His own inner quest and oscillation between the modern society and tribal society is the basic conflict presented in the novel. The second type of conflict is about the two different realities. As mentioned before, one is the notion of life associated with modern and materialistic society, while the other is tribal society. Both are realities and they are in conflict with each other. The third conflict is between the power structure -- the power of the nation-state versus the tribal society. The fourth conflict, which essentially is the underlying theme of Arun Joshi's novel, is the modernity versus tradition.

As discussed in the first chapter under the theoretical framework, the present novel, The Strange Case of Billy Biswas, also largely falls within the framework of modernity and tradition along with the conflict(s) associated with such themes. The author, Arun Joshi is significantly successful in presenting the dilemmas of modern day human beings. This is more relevant particularly in the context of Indian society and polity. Indian society is largely traditional, while the policy is modern in nature that was imposed as part of the colonial rule. Thus, this novel is pertinent for understanding the conflicts in the Indian society. The novel is more relevant in contemporary India in the context of numerous protests and movements emerging against the modern development projects like dams, mining, nuclear power plants, and industries among other aspects. In the recent times, many such protests and movements had emerged 
in India often questioning the validity of exploiting natural resources in the name of modernization and development.

However, the period that the novel was set in - the 1960s - as Romi and Billy talk about Nehru's death. Thought, the death of Nehru left certain gloominess and uncertainty about India's future, there was by and large the mood was sanguine about India's future vis-a-vis its development and role in the world affairs. Romi even highlights the concern that the country might disintegrate in the absence of Nehru. Nonetheless, there was optimism for new leadership and India going on the path of modern development. For that period, the talk of contemporary development debate was new and too early. For instance, the incidents of protest against dams on river Narmada, or the more recent Singur and Nandigram protests in West Bengal or the tribal protests against mining in Orissa (Odisha) are some of the examples to understand the change in the contours of development debates. It is in this backdrop that one needs to understand Arun Joshi's novels. Apart from development, another issue that has dominated Indian society and polity in the recent times has been the issue of corruption.

\section{REFERENCES}

Abraham, A. P. (2013). Patrick White's Voss and Arun Joshi's The Strange Case of Billy Biswas: A metaphysical journey into the self". Language in India, 13(10), 51-58.

Bruce, D., \& Amanda Marlin, A. (2012). Council of Ministers of Education, Canada: A Report on Literature Review on Factors Affecting the Transition of Aboriginal Youth from School to Work.

Chithra, V. B., \& Sankar, K. R. (2012). Alienation and identity in Arun Joshi's The Strange Case of Billy Biswas. Research Link, 11(1), 37-39.

Dhawan, R. K. (1992). The fictional world of Arun Joshi. In R. K. Dhawan (ed.). The Novels of Arun Joshi. New Delhi: Prestige.

Eltigani, S., \& Ateem, M. (2007). The root causes of conflicts in Sudan and the making of the Darfur tragedy. Conflict Prevention and Development CoOperation in Africa: A Policy Workshop, 2007. http://www.operationspaix.net/DATA/DOCUMENT/5425 v The_root_c auses_of_conflicts_in_Sudan_and_the_makink_of_the_Darfur_tragedy.p $\mathrm{df}$

Maise, S. (2015). The resurgent tribal agenda in Saudi Arabia. Arab Gulf States Institute in Washington, 5. http:/wwww.agsiw.org/wpcontent/uploads/2015/07Maisel_Resurgent-Tribal-Agenda.pdf 
Navaneethamani, V. (2012). Arun Joshi's The Strange Case of Billy Biswas: A universal myth of primitivism. The Criterion: An International Journal in English, 3(1), 1-5.

Nawale, A. M. (2012). Return to nature: A study of Arun Joshi's The Strange Case of Billy Biswas. http:/bcjms.bhattercollege.ac.in>, accessed on 9th May 2015.

Sharma, A., \& Raizada, S. (2013). Existentialism in Arun Joshi's novels. Research on Humanities and Social Sciences, 3(8). www.iiste.org.

Soule, A. (2015). Ethics of development: An ecocritical reading of The Strange Case of Billy Biswas and Gift in Green. Humanities and Social Sciences Review, $4(1), 457-461$.

Srikant, P. (2009). Tribal movement in Orissa: A struggle against modernisation? ISEC Working Paper-215, Bangalore: Institute for Social and Economic Change.

Teuton, S. (2006). A question of relationship: Internationalism and assimilation in recent American Indian studies. American Literary History, 18(1), 152174. Https://doi.org/10.1093/alh/ajj008

Vaishya, V. K. (2014). Cross-Culture and Theme of Alienation in Arun Joshi's The Strange Case of Billy Biswas. The Criterion: An International Journal in English, 5(4), 373-78.

Vanitha, S. (2014). Nature and spirituality in Arun Joshi's The Strange Case of Billy Biswas. IOSR Journal of Humanities and Social Sciences, 19(7), 50-52.

Yadav, K. (2013). Search for individuality in the novel of Arun Joshi: The Strange Case of Billy Biswas. International Journal Innovative Research E Studies, 2(7), 258-265.

\section{Authors' Brief CV}

Bikki Anupama is an Associate Professor in Kallam Haranadha Reddy institute of Technology. She has obtained her doctoral degree from Acharya Nagarjuna University, Guntur, AP, India in 2016. Her areas of interests are Indian literature, Cultural studies and Feminist issues.

Mantri Venkata Raghu Ram is a Professor of English and Head, Department of Sciences and Humanities at Vasireddy Venkatadri Institute of Technology (VVIT), Guntur, India. He has guided many Ph. D and M. Phil scholars. He has published research articles in a number of international and national journals. His areas of interest include postcolonial literature, ELT, commonwealth literature and Cultural studies. 
